\title{
The Current Situation of Marriage Problems in Contemporary Society: Is Marriage in Crisis? \\ Xinyue Chang ${ }^{1, *}$
}

\author{
${ }^{1}$ The University of California, Santa Barbara \\ *Email: xinyuechang@ucsb.edu
}

\begin{abstract}
People today have more freedom than they did in the past, with less pressure and limitation to some extent, which leads to a reluctance to marriage; however, this behavior eventually leads to society's inclination to age in the future. The author starts with 1) increasing independence in women, 2) independent consciousness of people in society, and 3) the meaning of marriage to people to discuss whether marriage is in crisis.
\end{abstract}

Keywords: Sociology, Marriage, Gender, Education

\section{INTRODUCTION}

In A Tale of Two Cities ${ }^{[1]}$, Dickens writes that "[i]t was the best of times, it was the worst of times," which can also describe the current situation of the marriage. Contemporary social culture allows people to pursue more freedom than before without much pressure and restriction to some extent, which causes the unwillingness to marry among people. Unfortunately, this action eventually brings society the tendency of aging in the future. Historian ${ }^{[2]}$ Nancy Cott claims that Americans have seen marriage as the core of good families and communities since colonial times and that it is essential to the operation of democracy itself (Hull et al., 2010). However, about half of all marriages now end in divorce. One of the reasons is that given ${ }^{[3]}$ the intrinsic importance of marital relationships for many people and the robust associations of marital quality with mental and physical health, it is disconcerting that marital quality normatively declines over time (VanLaningham, Johnson, \& Amato, 2001). In my opinion, the increasing awakening of independence among women and the rising independent consciousness of people who are unwilling to be manipulated is promoting the declining marriage rate in America. The pattern of intimacy is also changing over time. However, marriage is not in crisis because marriage is still regarded unconsciously as a perfect end of love and a new start of the journey between couples.

\section{INCREASING AWAKENING OF INDEPENDENCE AMONG WOMEN}

Firstly, the continuously decreasing rate of marriage is a corollary of the growing awareness of the independence of women. Brady ${ }^{[4]}$ describes that a wife in a family in 1970 is more like a super-housekeeper that not only takes good care of babies and her husband but should also satisfy her husband in every dimension in life (2015). However, women who are currently receiving an equal opportunity of education to men no longer focus on the topic of how to be a good wife and regard marriage as their whole life. Women at present have more choices than before. Some statistic ${ }^{[5]}$ in the pew research center shows that the percentage of young women enrolled in college has more than doubled in the last 40 years (Wang \& Parker, 2020). Apparently, there is an increasing number of well-educated women appearing in society as independent individuals who can get a good job, which means that they can earn a high enough salary to support their lives. Therefore, with the increasing educational levels received by women, they no longer regard marriage as their survival tool so that they are not likely to compromise themselves by marriage for any other reasons. Eventually, this action leads to a declining marriage rate. However, data ${ }^{[6]}$ also shows that the majority of never-married individuals state that they haven't met the right person and 58 percent of respondents say they want to marry eventually (Parker \& Stepler, 2020) (See Figure 1). These statistics indicate that people are still willing to accept marriage because they have an expectation of 
marriage for love but not the radical rejection of marriage.

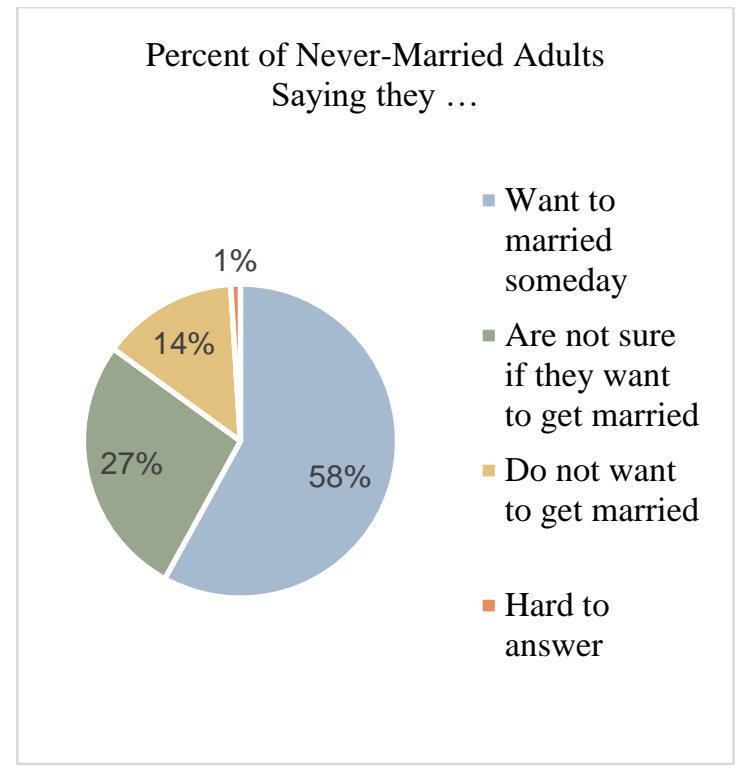

Figure 1 Among Adults Who Never Married, Narrow Majority Want to Marry Someday

Source: Survey of U.S. adults conducted Aug. 8-12, 2017.

\section{RELEASING THEMSELVES FROM THE CONSTRAINTS OF BEING PUSHED AROUND}

In America, the personality of people who are unwilling to be manipulated by their parents contributes to the declining marriage rate. Because of the constant development of society, which offers people variable resources to connect with this world, in recent years, people have developed own their independent thoughts to a great extent, which older people do not easily control. Many people were determined that they did not want to be married in an arranged marriage, which conveys the true feeling of many people [7] (Ramanathan, 2015). Because people are exposed to many dimensions of resources such as the internet, they own many methods to interact with the outside world to obtain a plethora of information. They are not as easy as before to reconcile to the arrangement by parents. In addition, Waltman ${ }^{[8]}$ states that loving someone entails making a conscious decision to treat them with love, respect, loyalty, and compassion on a regular basis, which also works on marriage (2015). I believe that marriage is also a choice of deciding whom people will live within the rest of their lives with commitment and happiness but not being arranged by parents with the saying of "love comes later." The independence of thoughts and variable internet resources provide plenty of choices for people to perceive relationships of people, which result in the decreasing marriage rate.

\section{THE PATTERN OF INTIMACY IS ALWAYS CHANGING.}

Giddens [9] notes that intimacy is experiencing significant upheaval in modern Western countries (2013). The romantic love paradigm, which emphasizes marital stability and balanced gender roles, is being superseded by "confluent love" (2013). The pure relationship is an ideal in the confluent love model, one that is entered into for its own purpose and maintained for as long as both lovers are satisfied enough to stay.

A [9] pure relationship's partners build trust by frequent conversation, but the danger of a split is always there. Modernization and globalization have resulted in the emergence of confluent love (2013). As familial and religious traditions fade away, people create their own biographies via highly personalized choices, including intimate partner selection, with the overriding objective of achieving happiness. Within the institution of marriage, the social standards that define and regulate people's conduct are eroding. People nowadays have more options for how they marry, as well as when and if they marry at all. The rise of unmarried childbearing, the shifting distribution of work in the house, the expansion of unmarried cohabitation, and the introduction of same-sex marriage have all contributed to the deinstitutionalization of marriage. People are actively questioning the link between marriage and parenthood, the concept of complementary gender roles, and even the link between marriage and heterosexuality as a result of these largescale changes. Individuals ${ }^{[10]}$ feel freer to marry later, break unpleasant marriages, and avoid marriage entirely in such circumstances, according to Cherlin, despite the fact that marriage still has significant symbolic meaning for many people, partially as a marker of success and prestige (2004).

\section{THE MEANING OF MARRIAGE TO PEOPLE}

Currently, many people in America believe that marriage is in crisis because of the continuously decreasing marriage rate and the rise in divorce and widowhood. It is conceivable for individuals to think that marriage involves troubles in America. However, marriage is not in crisis. According to freshly published census statistics ${ }^{[6]}$, half of all people in the United States are married now, down from a high of 72 percent in 1960 (Parker \& Stepler, 2020). This is a significant increase from $1960^{[7]}$, when only 13 percent of married individuals had previously been married, to 1980, when 17 percent of people had previously been married (See Figure 2). The percentage of people who have recently 


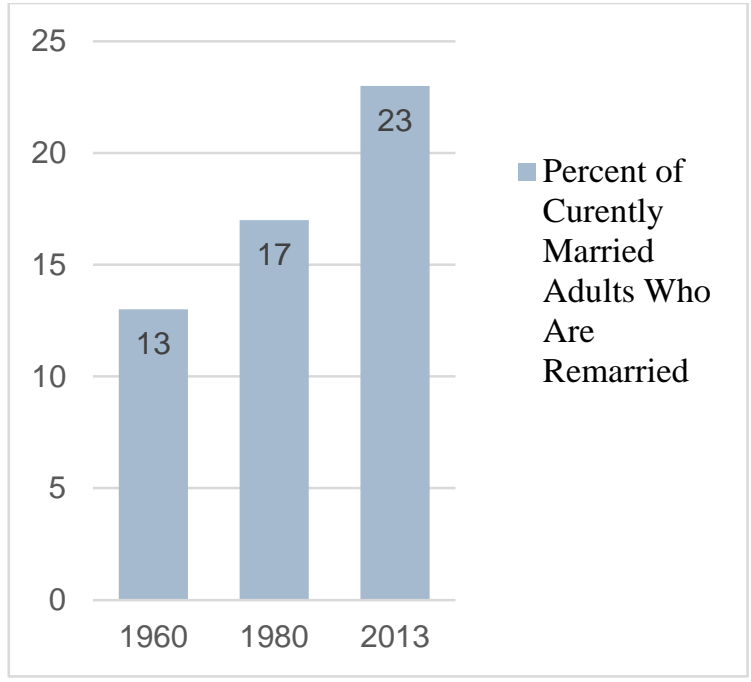

Figure 2 Prevalence of Remarriage

Source: Pew Research Center analysis of 1960 and 1980 Decennial Census (1\% IPUMS) and 2013

American Community Survey (1\% IPUMS)

married climbs to 29 percent (Livingston, 2019). These statistics indicate that there are still many people who are willing to get married even though they once divorced. If marriage is in crisis, those people who have divorced will not be ready to remarry again. In fact, they start a new marriage instead of being single, which means people do not radically reject marriage. Therefore, although the rate of marriage is decreasing, people do not entirely refuse to remarry.

\section{CONCLUSION}

Finally, although the reluctance of getting married can be ascribed to many causes, marriage is still not in crisis because many people still regard it as a transition of a new beginning of life. For example, most couples who deeply love each other and have already kept a long stable relationship will finally consider stepping into marriage. The reason for people getting married is that wedlock is not only the embodiment of love but is also protected by law. Marriage is a natural process of couples who love each other and have enough sense of security and loyalty. Then, they will establish their family, mutually respect and tolerance, and make a lifelong commitment. However, if an increasing number of people decide not to marry anyone else, the rate of marriage and birth will continuously decrease. This declination will bring the tendency of aging to society, which means they lack productivity in the future and bring extra burdens on the national economy.

In conclusion, given the negative consequence society has made by the reluctance to get married, it is not difficult to conclude that the increase of awareness of independence among women and the unwillingness to be manipulated play roles in the preference of not getting married in recent years. However, with the rise of the remarried rate, marriage should not be seen in crisis because many people still have expectations of marriage and are willing to step into marriage again. Today, marriage is not a rash decision influenced by other people, but a prudent choice that accounts for two people's life. More importantly, people should be educated that marriage is a choice, which means a stable relationship with equality. Marriage is the soil, but growth and companionship are the bloom of marriage.

\section{AUTHORS' CONTRIBUTIONS}

The authors confirm contribution to the paper as follows: all reading and writing completion: Xinyue Chang.

\section{ACKNOWLEDGMENT}

The authors would like to acknowledge Professor Shamus Khan from Princeton University for providing comments and assistance on the previous version of manuscripts.

\section{REFERENCES}

[1] Dickens, C. \& Dunn, H. (1921) A Tale of Two Cities. New York, Cosmopolitan Book Corporation.

[2] Hull, K. E., Meier, A., \& Ortyl, T. (2010). The changing landscape of love and marriage. Contexts, 9(2), 32-37.

[3] VanLaningham, J., Johnson, D. R., \& Amato, P. (2001). Marital happiness, marital duration, and the U-shaped curve: Evidence from a five-wave panel study. Social Forces, 78, 1313-1341.

[4] Brady, J. (2015). I Want a Wife. In R. Atwan (Ed.), American Now (12th ed., pp. 390-394). essay, St Martin's Bedford.

[5] Wang, W., \& Parker, K. (2020, July 29). Women see value and benefits of college; men lag on both fronts, survey finds. Pew Research Center's Social \& Demographic Trends Project. Retrieved November 20, 2021, from https://www.pewresearch.org/socialtrends/2011/08/17/women-see-value-and-benefitsof-college-men-lag-on-both-fronts-survey-finds/.

[6] Parker, K., \& Stepler, R. (2020, May 30). As U.S. marriage rate hovers at $50 \%$, education gap in marital status widens. Pew Research Center. Retrieved November 20, 2021, from http://www.pewresearch.org/facttank/2017/09/14/as-u-s-marriage-rate-hovers-at50-education-gap-in-marital-status-widens/. 
[7] Ramanathan, L. (2015). They Didn't Want an Arranged Marriage. In American Now (12th ed., pp. 351-357). essay, Rowan Atwan, St Martin's Bedford.

[8] Waltman, K. (2015). Saying 'I Love You'. In American Now (12th ed., pp. 346-349). essay, Rowan Atwan, St Martin's Bedford.

[7] Livingston, G. (2019, December 31). Trends in remarriage in the U.S. Pew Research Center's Social \& Demographic Trends Project. Retrieved November 20, 2021, from https://www.pewresearch.org/socialtrends/2014/11/14/chapter-1-trends-in-remarriagein-the-u-s/.

[10] Giddens, A. (2013). The transformation of intimacy: Sexuality, love and eroticism in modern societies. John Wiley \& Sons.

[11] Cherlin, A. J. (2004). The deinstitutionalization of American marriage. Journal of marriage and family, 66(4), 848-861. 